\title{
Mechanical Harvesting of Camelina: Work Productivity, Costs and Seed Loss Evaluation
}

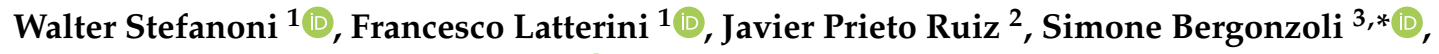 \\ Consuelo Attolico ${ }^{1}$ and Luigi Pari ${ }^{1}$ (i) \\ 1 Consiglio per la Ricerca in Agricoltura e l'Analisi dell'Economia Agraria (CREA), Centro di Ricerca \\ Ingegneria e Trasformazioni Agroalimentari, Via della Pascolare 16, 00015 Monterotondo, Italy; \\ walter.stefanoni@crea.gov.it (W.S.); francesco.latterini@crea.gov.it (F.L.); consuelo.attolico@crea.gov.it (C.A.); \\ luigi.pari@crea.gov.it (L.P.) \\ 2 Camelina Company Espana, Camino de la Carrera, 11, Fuente el Saz de Jarama, 28140 Madrid, Spain; \\ j.prieto@camelinacompany.es \\ 3 Consiglio per la Ricerca in Agricoltura e l'Analisi dell'Economia Agraria (CREA), \\ Centro di Ricerca Ingegneria e Trasformazioni Agroalimentari, Via Milano 43, 24047 Treviglio, Italy \\ * Correspondence: simone.bergonzoli@crea.gov.it
}

Received: 16 September 2020; Accepted: 12 October 2020; Published: 13 October 2020

\begin{abstract}
Camelina is a low input crop than can be cultivated in rotation with cereals to provide vegetable oil suitable for bioenergy production, industrial applications and even as source of food for livestock. At large scale farming, camelina seeds are currently harvested using a combine harvester, equipped with a cereal header, but the literature still lacks the knowledge of the performance of the machine, the harvesting cost and the related loss of seeds. The present study aims to fulfill that gap by reporting the results obtained from an ad hoc harvest field test. Camelina seed yield was $0.95 \mathrm{Mg} \mathrm{ha}^{-1}$ which accounted for the $18.60 \%$ of the total above ground biomass. Theoretical field capacity, effective field capacity and field efficiency were $3.38 \mathrm{ha} \mathrm{h}^{-1}, 3.17 \mathrm{ha} \mathrm{h}^{-1}$ and $93.7 \%$ respectively, albeit the seed loss was $80.1 \mathrm{~kg} \mathrm{ha}^{-1} \mathrm{FM}(7.82 \% w / w$ of the potential seed yield). The presence of material other than grain was rather high, $31.77 \% w / w$, which implies a second step of cleaning to avoid undesired modification of the seed quality. Harvesting cost was estimated in $65.97 € \mathrm{ha}^{-1}$. Our findings provide evidence on the suitability to use a conventional combine harvester equipped with a cereal header for the harvesting of camelina seeds, although some improvements are required to reduce both seed loss and impurities.
\end{abstract}

Keywords: bioenergy; oil crops; work performance; harvesting loss

\section{Introduction}

The European Community has been facing ambitious challenges concerning the reduction of nonrenewable sources for energy production during the last decades. The new Renewable Energy Directives REDI and RED II aim to promote the exploitation of natural feedstocks while avoiding competition with food production, as for instance, the set target of 3.5\% production of advanced biofuels in 2030 using either lignocellulosic residues or non-food crops [1]. Agriculture can significantly contribute to tackle the issue [2] providing a large spate of lignocellulosic residues [3-5] as well as energy crops for biofuel production [6,7]. Furthermore, biomolecules synthetized by energy crops can surrogate oil-derived compounds in several industrial sectors [8] to feed the so-called "green chemistry" which encompasses the production of many products, as solvents, cosmetics, building materials and biodegradable plastics [9]. Herbaceous crops are gaining interest across Europe as their biomolecules find many applications in the energy and industrial sectors [10]. Among them, camelina 
(Camelina sativa L.) is an attractive one since the seeds exhibit high oil content (30-49\%) which is suitable for several industrial applications. Some studies investigated the possibility to exploit the camelina oil as valid alternative to fossil fuels and petroleum derivate compounds [11,12]. The critical aspects of using vegetable oil for fuel production are mainly linked to cost competitiveness of such industrial process [13,14]. In fact, Keske et al. (2013) reported the cultivation of camelina seeds for biodiesel production to be convenient for diesel fuel price higher than $1.31 \$ \mathrm{~L}^{-1}$ [15]. Moreover, Yang et al. 2015 investigated the quality of the biodiesel fuel derived from the transesterification of camelina oil and found the fuel properties being in compliance with both American and European standards (e.g., ASTM D6751 and EN 14214) although the poor oxidative stability [16]. Jet fuel production is also possible from camelina oil $[17,18]$ and Natelson et al. (2015) reported a break-even selling price of $0.80 \$ \mathrm{~kg}^{-1}[19]$.

Moreover, camelina seeds are also suitable as a source of food for livestock [20-22], aquaculture [23,24] and feedstock for agrochemical, medical and veterinary products [25-27]. Additionally, the meal obtained from the oil extraction contains a high level of $\alpha$-linolenic and for this reason, it can be used in animal diets resulting in an increase in the market value of the crop [28]. In facts, the same authors have recently reported that camelina meal can be incorporated into the poultry diet as a source of energy, protein, and essential $n-3$ and $n-6$ fatty acids and provided at low levels ( 5 up to $10 \%$ ) no changes in egg production or egg quality were found. Thus, the multiple usage of camelina seeds makes it interesting for biorefinery industries [29]. Another key issue which makes camelina particularly interesting is its adaptability to different environmental conditions [30]. Camelina can be indeed cultivated as a low input crop and on poor or marginal soils [31,32] and even in double cropping regime with cereal and other agricultural species [33-38] thus, showing interesting features as a sustainable crop as well [18,39]. According to Lohaus et al. (2020), in semi-arid regions of North America, $86.4 \mathrm{~L} \mathrm{ha}^{-1}$ of biodiesel $(9.45 \% \mathrm{v} / \mathrm{w}$ of the seeds yield) can be derived from camelina cropping [40].

However, the main concerns arising with camelina cropping for biofuel production are linked the high costs of the supply chain, which currently makes it 30\% more costly than petroleum derived fuels [41]. Moreover, the competition for land between food and non-food crops it is also nourished, particularly if considering that more than $95 \%$ of the current biodiesel production worldwide relies on the use of edible vegetable [42,43]. Although the possibility to cultivate camelina on marginal lands can make its supply chain ethically acceptable, costs of harvesting and logistic must be investigated to make the camelina cropping economically sustainable too. Most of the costs related to the production of biodiesel are related to the feedstock [44] and the development of new technologies in the agriculture sector can lower them significantly, particularly at the harvesting stage [45]. Camelina seeds can be mechanically harvested to keep costs lower, by using a combine harvester equipped with cereal header [46]. However, seeds loss can be high since they are very small and light in weight (1000-seed weight ranges between 0.8 and $1.8 \mathrm{~g}[47,48]$ and the proper setting of the combine harvester is fundamental to keep such loss as low as possible [49]. The presence of weeds among camelina plants can further contribute to increase that loss [50]. The lack of knowledge of such important aspects leaves profound uncertainty on the practical outcomes of camelina cropping.

Notwithstanding the growing importance of camelina as a multipurpose oil crop, few studies have focused on the evaluation of work productivity, costs, and seeds loss in mechanical harvesting. For instance, Sintim et al. (2016) found $11.60 \%$ w/w of seed loss using a plot combine harvester [51], while Stolarski et al. (2019) recently reported the harvesting cost per surface unit of $46.70 € \mathrm{ha}^{-1}$ when using a New Holland (New Holland, PA, USA) combine harvester [52]. However, the performance and the harvesting costs of conventional combine harvester have not been tested yet although such information plays an important role in the decision making of farmers and other stakeholders.

Therefore, this study represents the first comprehensive investigation of camelina seeds harvesting in Spain reporting the work productivity, harvesting costs and seed loss related to the use of a conventional combine harvester, and it aims to provide the literature with relevant information for farmers and large enterprises. 


\section{Materials and Methods}

\subsection{Field Site}

The test was carried out in the village of Villafruela, Burgos (Castilla y Leon, Spain) during the 27th week of 2020 (Figure 1). The field area was 3.82 ha, the altitude $912 \mathrm{~m}$ a.s.l. with a negligible slope value.

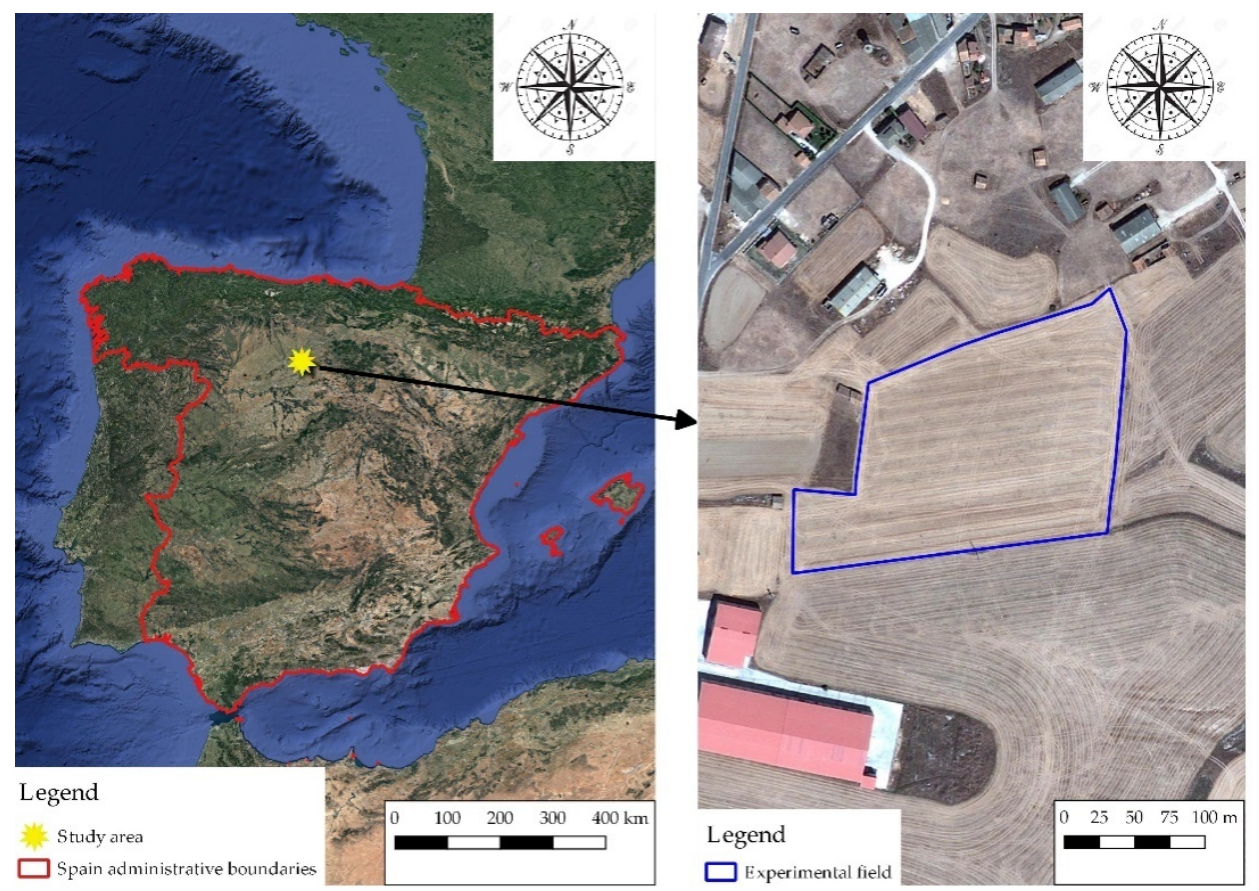

Figure 1. Map of the experimental field in Castilla y Leon region of Spain.

The cultivar Alba, variety suitable for cultivation in Mediterranean climate, was sown in early December 2019 at the rate of $8 \mathrm{~kg} \mathrm{ha}^{-1}$ and grown under conventional farming regime. Fertilizer was provided twice at the rate of $250 \mathrm{~kg} \mathrm{ha}^{-1}$ of NPK 8-15-15 and $250 \mathrm{~kg}^{-1}$ of liquid Nitrogen fertilizer (32\%) in winter and April, respectively. Successively, herbicide was applied for weed control.

The edge effect on the crop was excluded by selecting a 2 hectares homogeneous area within the field. The rest was preventively harvested but not included in the calculations.

\subsection{Pre-Harvest Tests: Theoretical Biomass Assessment}

Before harvesting, 10 sample plots of $1 \mathrm{~m}^{2}$ each were randomly selected to evaluate the whole aerial biomass (i.e., straw, siliques, and seeds). Plants were cut at collect level and shipped outside the field, then counted and measured in weight and height. Siliques and seeds were removed manually from the plants and weighed separately. Successively, siliques, seeds and a sample of straw form each sample plot were put in plastic sealed bags and shipped to the laboratory of Research Centre for Engineering and Agro-Food Processing (CREA-IT) for further measurements as: theoretical yield of seed, dry weight (DW), bulk density and moisture content. Dry weight and moisture content were measured according to the EN ISO 18134-2:2017 standard [53]. The bulk density and 1000 seed-weight were also measured; seeds bulk density $\left(\mathrm{kg} \mathrm{m}^{-3}\right)$ was assessed according to ISO 17828:2015 [54] in 10 randomly selected samples. 


\subsection{Combine Harvester}

The contractor provided the combine harvester, a John Deere W650 (Figure 2) equipped with a conventional cleaning shoe and a $6.7 \mathrm{~m}$ wide cereal header. The machine was driven by $240 \mathrm{~kW}$ diesel engine and the setting applied (Table 1) was kept constant throughout the test.

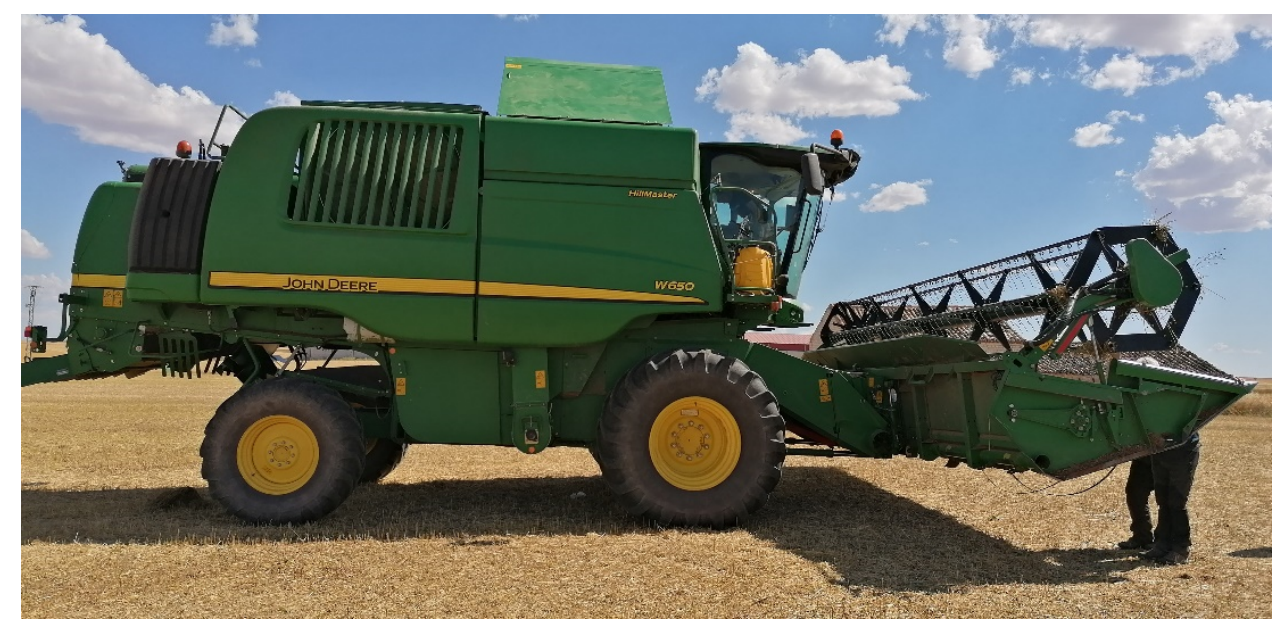

Figure 2. John Deere W650 combine harvester equipped with a cereal header.

Table 1. Combine harvester (John Deere W650) settings used during harvesting of camelina.

\begin{tabular}{cc}
\hline Parameter & Setting \\
\hline Rotor speed $(\mathrm{rpm})$ & 800 \\
Cleaning Fan Speed $(\mathrm{rpm})$ & 700 \\
Openings of Upper Sieve $(\mathrm{mm})$ & closed \\
Openings of Lower Sieve $(\mathrm{mm})$ & 5 \\
Straw treatment & threshed \\
\hline
\end{tabular}

\subsection{Harvesting Performance}

Five sample plots were randomly chosen within the selected area to test the performance of the combine harvester. The surface of each plot ranged between 1000 a $2500 \mathrm{~m}^{2}$, and the study of the working times was carried out according to methodology proposed by Comité International d'Organisation Scientifique du Travail en Agriculture (CIOSTA) methodology and the recommendations from the Italian Society of Agricultural Engineering (A.I.I.A.) 3A R1 [55]. The assessment evaluation of the working speed allowed to identify the Theoretical Field Capacity (TFC, ha ${ }^{-1}$ ), the Effective Field Capacity (EFC, ha $\mathrm{h}^{-1}$ ) and Material Capacity $\left(\mathrm{MC}, \mathrm{Mg} \mathrm{h}^{-1}\right.$ ). The ratio between EFC and TFC is named Field Efficiency (FE). The time required for discharge operations was recorded and considered as accessory time.

At the end of the harvesting operation the material collected was discharged onto a trailer and weighted for the determination of the seed yield at the farm scale. A sample of the collected material was taken and put in sealed bag in order to determine the moisture content, the percentage of MOG (Material Other than Grain, e.g., weed seeds, threshed siliques, part of weed plants) and the 1000-seeds weight.

\subsection{Costs Analysis}

The contractor, via interview, provided purchase and operating costs of the combine harvester, whilst the working performance of the machine was taken from the results of field tests and used as primary data. Finally, standard values for calculation were taken from CRPA (Research Centre on Animal productions) methodology [55]. 
Hourly costs of combine harvester were calculated considering the market value of the agricultural machinery [56]. The price of the machine was discounted to 2019, using the lending rate of $3 \%$ provided by Banca d' Italia Institute [57]. Applied parameters for economic evaluation are given in Table 2.

Table 2. Parameters for cost analysis.

\begin{tabular}{cccc}
\hline & Parameter & Measure Unit & Value \\
\hline Machine & Power & $\mathrm{kW}$ & 240 \\
\hline Financial costs & Investment & $€$ & $380,000.00$ \\
& Service life & year & 10 \\
& Service life & $\mathrm{H}$ & 3000 \\
& Resale & $\%$ & 19.00 \\
& Resale & $€$ & $72,200.00$ \\
& Depreciation & $€$ & $307,800.00$ \\
Annual usage & $\mathrm{h} \mathrm{year}$ & 312 \\
& Interest rate & $\%$ & 3 \\
\hline \multirow{2}{*}{ Fixed costs } & Ownership costs & $€$ year $^{-1}$ & $30,780.00$ \\
& Interests & $€$ year $^{-1}$ & 6783.00 \\
& Machine shelter & $\mathrm{m}^{2}$ & 30.82 \\
& Value of the shelter & $€ \mathrm{~m}^{-2}$ & 100.00 \\
& Value of the shelter & $€$ year $^{-1}$ & 61.64 \\
& Insurance & $€$ year $^{-1}$ & 950.00 \\
\hline Variable costs & Repair factor & $\%$ & 40 \\
& Repairs and maintenance & $€ \mathrm{~h}^{-1}$ & 52.69 \\
& Fuel cost & $€ \mathrm{~L}^{-1}$ & 0.57 \\
& Fuel consumption & $\mathrm{L} \mathrm{h}^{-1}$ & 37.37 \\
& Fuel cost & $€ \mathrm{~h}^{-1}$ & 21.30 \\
& Lubricant cost & $€ \mathrm{~L}^{-1}$ & 3.03 \\
& Lubricant consumption & $\mathrm{L} \mathrm{h}^{-1}$ & 0.36 \\
& Lubricant cost & $€ \mathrm{~h}^{-1}$ & 1.08 \\
& Worker salary & $€ \mathrm{~h}^{-1}$ & 11.5 \\
\hline & & &
\end{tabular}

\subsection{Post-Harvesting Test: Seed Losses}

The total seed loss (TSL) was calculated as the mere difference between the theoretical biomass assessed during the pre-harvest and the effective quantity of seeds collected and weighted at the farm scale. This includes the seed loss due to the impact of the combine header and the ineffectiveness of the cleaning shoe of the machine to discriminate the seeds from the rest of the biomass processed. Therefore, a tarpaulin was installed at the end of two sample plots to collect the seeds lost by the combine harvester from the sieves and straw walkers. The entire amount of biomass expelled by the machine was thus collected by the tarpaulin laying on the ground. The biomass was shipped to the laboratory, then weighted and sieved for assessing the amount of seeds lost by the combine harvester (CSL). The weight of the seeds found was referred to a surface of $13.4 \mathrm{~m}^{2}$ given by the width of the combine header $(6.4 \mathrm{~m})$ multiplied by the length of the tarpaulin $(2 \mathrm{~m})$. Furthermore, the 1000 seed-weight was recorded in order to compare it with the 1000 seed-weight of the harvested camelina seeds. The loss of seeds due to the impact (ISL) of the combine harvester with the siliques is calculated as TSL-CSL.

\subsection{Statistical Analysis}

Statistical analysis was performed to investigate the difference between the 1000 seed-weight of harvested seeds and not-harvested ones. Normality and Homoscedasticity were tested with Shapiro test and F test, respectively. Considering that Shapiro test revealed that the distributions of the data could not be considered normal, the investigation of the presence of statistically significant 
differences between 1000 seed-weight of harvested seeds and not harvested ones was carried out through Kruskal-Wallis test. The analysis was performed with Statistica 7.0 software [58].

\section{Results}

\subsection{Biomass Characterization}

Results of the pre-harvest tests are given in Table 3.

Table 3. Results of pre-harvest tests.

\begin{tabular}{cccc}
\hline Parameter & Measure Unit & Average & St.Dev. \\
\hline Harvested surface & ha & 3.82 & - \\
Number of plants & $\mathrm{N} \mathrm{m}^{-2}$ & 311 & 43 \\
Plant height & $\mathrm{cm}^{-1}$ & 70.53 & 6.27 \\
Straw weight & $\mathrm{Mg} \mathrm{ha}^{-1} \mathrm{FM}$ & 3.31 & 0.25 \\
Straw moisture content & $\%$ & 10.46 & 0.14 \\
Siliques weight & $\mathrm{Mg} \mathrm{ha}^{-1} \mathrm{FM}$ & 1.20 & 0.05 \\
Siliques moisture content & $\%$ & 7.27 & 0.59 \\
Potential seed yield & $\mathrm{Mg} \mathrm{ha}^{-1} \mathrm{FM}$ & 1.03 & 0.01 \\
Harvest Index (HI) & - & 0.186 & 0.013 \\
Seed moisture content & $\%$ & 5.18 & 0.58 \\
\hline
\end{tabular}

At the harvesting, 311 plants per $\mathrm{m}^{2}$ were standing on field and the plants measured $71 \mathrm{~cm}$ in height on average. Straw, siliques and seed moisture were $10.46 \%, 7.27 \%$ and $5.18 \%$ respectively.

As shown on Figure 3, the most abundant aboveground biomass was represented by straw which accounted for the $59.67 \%$ of the total, then siliques and seeds accounted for the $21.73 \%$ and the $18.60 \%$ respectively. Harvest Index (HI) resulted in 0.186.

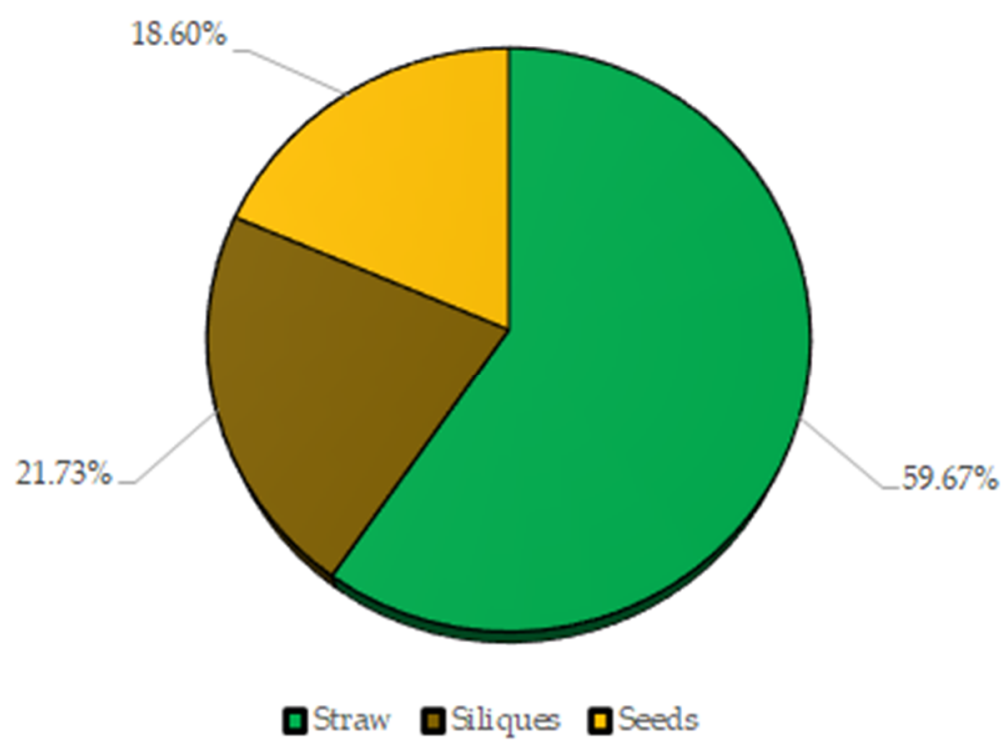

Figure 3. Percentage of straw, siliques and seeds of the aboveground biomass.

\subsection{Work Performance and Costs Analysis}

The performance of the combine harvester is given in Table 4.

The working speed of $5.05 \mathrm{~km} \mathrm{~h}^{-1}$ allowed to reach a TFC and EFC values as high as $3.38 \mathrm{ha} \mathrm{h}^{-1}$ and $3.17 \mathrm{ha} \mathrm{h}^{-1}$, respectively. Since the seed yield was $0.95 \mathrm{Mg} \mathrm{ha}^{-1}$ fresh matter (FM), the MC was $3.01 \mathrm{Mg} \mathrm{h}^{-1} \mathrm{FM}$ while the FE reached the value of $93.7 \%$. 
Table 4. Work performance analysis results.

\begin{tabular}{cccc}
\hline Parameter & Measure Unit & Average & St.Dev. \\
\hline Seed yield & $\mathrm{Mg} \mathrm{ha}^{-1} \mathrm{FM}$ & 0.95 & - \\
Working speed & $\mathrm{km} \mathrm{h}^{-1}$ & 5.05 & 0.35 \\
Theoretical Field Capacity (TFC) & $\mathrm{ha} \mathrm{h}^{-1}$ & 3.38 & 0.24 \\
Effective Field Capacity (EFC) & $\mathrm{ha} \mathrm{h}^{-1}$ & 3.17 & 0.20 \\
Field Efficiency (FE) & $\%$ & 93.7 & 0.83 \\
Material Capacity (MC) & $\mathrm{Mg} \mathrm{h}^{-1} \mathrm{FM}$ & 3.01 & 0.19 \\
\hline
\end{tabular}

The working performance allowed to calculate the harvesting costs (Table 5) of $210.21 € \mathrm{~h}^{-1}$, $65.97 € \mathrm{ha}^{-1}$ and $69.42 € \mathrm{Mg}^{-1} \mathrm{FM}$.

Table 5. Results of costs analysis.

\begin{tabular}{ccc}
\hline Parameter & Measure Unit & Value \\
\hline Costs per time unit & $€ \mathrm{~h}^{-1}$ & 210.21 \\
Costs per surface unit & $€ \mathrm{ha}^{-1}$ & 65.97 \\
Costs per biomass unit & $€ \mathrm{Mg}^{-1} \mathrm{FM}$ & 69.42 \\
\hline
\end{tabular}

\subsection{Seed Loss and Presence of MOG}

Results about seed loss and MOG analysis are given in Table 6.

Table 6. Seed loss and MOG analysis. Weights are given in FM.

\begin{tabular}{cccc}
\hline Parameter & Measure Unit & Average & St.Dev. \\
\hline Total Seed loss (TLS) & $\mathrm{Mg} \mathrm{ha}^{-1}$ & 0.0806 & - \\
Total Seed loss (TLS) & $\% w / w$ & 7.82 & - \\
Combine Seed Loss (CSL) & $\mathrm{Mg} \mathrm{ha}^{-1}$ & 0.0598 & - \\
Combine Seed Loss (CSL) & $\% w / w$ & 5.80 & - \\
Impact Seed Loss (ILS) & $\mathrm{Mg} \mathrm{ha}^{-1}$ & 0.0208 & - \\
Impact Seed Loss (ILS) & $\% w / w$ & 2.02 & - \\
Bulk density of collected material & $\mathrm{kg} \mathrm{m}^{-3}$ & 439.947 & 43.064 \\
Bulk density of cleaned seed & $\mathrm{kg} \mathrm{m}^{-3}$ & 642.332 & 7.435 \\
Material Other than Grain (MOG) & $\% w / w$ & 31.77 & 3.10 \\
Moisture content of harvested seeds & $\%$ & 15.71 & 0.53 \\
1000 seed-weight of harvested seeds & $\mathrm{g}$ & 1.1925 & 0.0168 \\
1000 seed-weight of not-harvested seeds & $\mathrm{g}$ & 1.2074 & 0.0113 \\
\hline
\end{tabular}

The TSL resulted in $80.1 \mathrm{~kg} \mathrm{ha}^{-1} \mathrm{FM}\left(7.82 \%\right.$ w/w), whilst CSL was $59.8 \mathrm{~kg} \mathrm{ha}^{-1} \mathrm{FM}(5.80 \% w / w)$. Therefore, the ISL calculated as the difference between TSL and CSL, was $20.8 \mathrm{~kg} \mathrm{ha}^{-1} \mathrm{FM}(2.02 \% w / w)$. The percentage of MOG found in the trailer was $31.77 \% w / w$. That high value triggered by the presence of poppy seeds (Papaver rhoeas L.) and fine biomass residues caused the decreasing of the bulk density measured in the harvested camelina seeds, if compared with the value found in the laboratory for sieved seeds. Moreover, the presence of green parts of weeds and camelina plants increased seed moisture by $10.53 \%$.

Finally, the means of 1000-seed weight recorded for the harvested seeds and CSL were not statistically different for the Kruskal Wallis test ( $p$ value 0.2482 ).

\section{Discussion}

\subsection{Biomass Characterization}

The average value of camelina seed yield $\left(1.03 \mathrm{Mg} \mathrm{ha}^{-1} \mathrm{FM}\right)$ is in line with the values provided by other authors in Spain [59]. Schillinger (2019) reported values ranging from 0.34 to $1.18 \mathrm{Mg} \mathrm{ha}^{-1}$ 
FM for cv. Calena in 8 years field experiment carried out in North-West USA [60]. Higher yield was experienced by Royo-Esnal et al. (2018) in Eastern Spain which reported values ranging from 0.92 to $2.31 \mathrm{Mg} \mathrm{ha}^{-1} \mathrm{FM}$ for cv. GP204 [36]. Imbrea et al. (2011) reported an average value of camelina seed yield for non-fertilized and fertilized fields of $0.93 \mathrm{Mg} \mathrm{ha}^{-1} \mathrm{FM}$ and $1.81 \mathrm{Mg} \mathrm{ha}{ }^{-1}$ FM, respectively [61]. These findings suggest that camelina is sensitive to the nutrient availability in the soil, although it is widely accepted that this species is suitable for marginal land cropping. High variability was also highlighted by Zanetti et al. (2020) suggesting a mindful approach when it comes to cultivate camelina as rotation crop with cereals [32]. Currently, other herbaceous oil crops are gaining interest through Europe, sometimes exhibiting higher seed yield, like canola (Brassica napus L.) and sunflower (Heliantus annuus L.) which yield $2.19 \mathrm{Mg} \mathrm{ha}^{-1} \mathrm{FM}$ and $1.97 \mathrm{Mg}^{-1} \mathrm{FM}$ of seeds on average, respectively. On the other hand, the global average seed yield for safflower (Carthamus tinctorius L.) is $0.99 \mathrm{Mg} \mathrm{ha}^{-1} \mathrm{FM}$ [62].

The quantity of residual biomass found in the present study (i.e., straw and siliques) accounted for the $71.40 \%$ of the total biomass, whilst Stolarski et al. (2019) reported only $44 \%$ [52]. Camelina residues were not collected but chopped and left on the ground as a common practice. This would contribute to the accumulation of organic carbon in the soil. Findings in recent studies highlight the suitability of camelina residues for bioenergy production [63-65]. However, the exploitation of agricultural residues as a source of bioenergy, encompasses a comprehensive study of all the costs generated during collection and transportation. This is fundamental to provide reliable clues on the feasibility of a given supply chain. Nevertheless, further investigations are encouraged since it could represent a valid alternative to the already known agricultural residue supply chains.

\subsection{Work Performance and Cost Analysis}

The working performance of the combine harvester resulting from this study is similar to that found in other crops where the same machine is used, moreover with similar setting. Unfortunately, the lack of knowledge found in literature regarding the mechanical harvesting of camelina seeds does not allow a direct comparison of our results with other's ones.

In wheat harvesting, for instance, the TFC of the combine harvester ranges from $2.61 \mathrm{ha} \mathrm{h}^{-1}$ to $3.72 \mathrm{ha} \mathrm{h}^{-1}$, the EFC is in the range of $1.92-2.28 \mathrm{ha} \mathrm{h}^{-1}$ while the FE lays between $67 \%$ and $83 \%[5,66,67]$. In our findings TFC, EFC and FE were $3.38 \mathrm{ha} \mathrm{h}^{-1}, 3.17 \mathrm{ha} \mathrm{h}^{-1}$, and $93.7 \%$ respectively. In harvesting camelina seeds, it seems that the combine harvester would perform better than in wheat grains harvesting. However, this difference can be explained by the average speed of the machine which was $5.05 \mathrm{~km} \mathrm{~h}^{-1}$ that could have been possible because of the wide headlands. In fact, the machine could quickly turn on the next pass without wasting time to undertake manoeuvres at the end of the plots.

The EFC found in other oil crops were also similar, although the combine harvesters were equipped with different headers. For instance, in sunflower harvesting Chaplygin et al. (2019) [68] reported the EFC ranging from 1.50 to $3.70 \mathrm{ha} \mathrm{h}^{-1}$, whilst Pari et al. $(2008,2016)[69,70]$, in cardoon (Cynara cardunculus L.) harvesting, reported the EFC ranging from 1.57 to $2.10 \mathrm{ha} \mathrm{h}^{-1}$. In those cases, the lower values resulted from the lower working speed, i.e., $3-4 \mathrm{~km} \mathrm{~h}^{-1}$, which was needed for a proper harvesting of the crops [46].

Harvesting cost for camelina seed harvesting was $65.97 € \mathrm{ha}^{-1}$ which is higher than the cost reported by Stolarski et al. (2019) which was $46.70 € \mathrm{ha}^{-1}$ [52]. However, it is similar to that reported by Semerci et al. in 2010 and 2019 tests conducted in sunflower harvesting, whom found the harvesting costs of 57.23 and $82.11 €$ ha $^{-1}$ respectively [71,72].

Nonetheless, when it comes to money, the harvesting cost are not the only parameter that is to be taken into account. The productivity and selling price of a given product are the major drivers in the farmers' decision making. Thus, in some cases, camelina cropping cannot compete with other oil crops. For example, the average global seed yield for sunflower, i.e., $1.97 \mathrm{Mg} \mathrm{ha}^{-1} \mathrm{FM} \mathrm{[62]} \mathrm{is} \mathrm{higher}$ than the usual seed yield reported for camelina in Spain [59], with harvesting costs per biomass unit $\left(69.42 € \mathrm{Mg}^{-1}\right)$ higher as well. A similar conclusion can be drawn if camelina seeds harvesting cost is 
also compared with wheat harvesting costs per biomass unit. Here, the higher yield of grains per unit of surface lowers the cost remarkably [5,73]. Additionally, wheat straw market can further contribute to generate an income for the farmers, which is still being missing for camelina straw.

\subsection{Seed Loss and Presence of MOG}

The TSL of $80.1 \mathrm{~kg} \mathrm{ha}^{-1} \mathrm{FM}$ (7.82\% of the potential seed yield) is mainly related to the combine harvester threshing and cleaning system (CSL), i.e., about $60 \mathrm{~kg} \mathrm{ha}^{-1} \mathrm{FM}$, whilst only $20.8 \mathrm{~kg} \mathrm{ha}^{-1} \mathrm{FM}$ were due to the impact of the combine harvester header (ISL) on siliques. Sintim et al. (2016) reported that $11.70 \%$ of the seeds were lost during the harvesting when using a plot harvester [51], which is supposed to be more accurate than common combine harvesters and then generating as low seed loss as possible. Thus, future studies should focus specifically on the possible available strategies for reducing such source of seed loss. Interestingly, the mean 1000 seed-weight measured for harvested seeds and lost seeds were not statistically different. Indeed, this highlights that there was not enough physical difference among seeds to trigger loss. In fact, the idea behind to such investigation was that those seeds lost by the combine harvester could differ from the others because some physical properties, such as weight, shape or volume that, in turn, could have been linked to different content of oil, proteins or carbohydrates [74]. This was not the case; therefore, the seed loss is to be related only to either the machine setting or the working speed. Camelina seeds are very light in weight, then they are very keen to be blown by the fan installed in the cleaning shoe of the combine harvester. On the other hand, the fan speed cannot be lowered too much otherwise MOG would increase significantly. Unless the cleaning shoe of the combine harvester is profoundly improved by customizing the sieves and fans for the specific harvesting of camelina seeds, lowering the working speed is the most simple and effective expedient for decreasing the loss of seeds.

During the harvesting, the loss of seeds should be as low as possible. For instance, the average seed loss in sunflower harvesting is approximately $2 \% w / w$ [69], which can be further lowered to $1 \%$ if some adjustments and modifications are applied to the header $[75,76]$. In canola seeds harvesting, if the combine harvester is equipped with a specific rapeseed header, seed loss ranges between 0.97 and $2.76 \% w / w$ [77-79]. Similar values of seed loss (3\%) are also reported in the literature for safflower [46], crambe (Crambe abyssinica R.E.Fr.) [80], and cardoon seeds [70].

However, the quantity of seeds lost (therefore the quantity of seeds harvested) is not the only parameter that should be carefully evaluated, but there is another noteworthy aspect to consider that is the high percentage of MOG (weed seeds and fine camelina residues) found in the harvested seeds. MOG is related to the capability of the combine harvester to discriminate efficiently seeds form impurities because they can affect negatively the quality of the seeds in different ways: by lowering the market value and, in the worst-case scenario, jeopardizing the proper conservation of the seeds. Our findings clearly show that the residuals from camelina plants blended with the harvested seeds increased their moisture content up to $15.71 \%$ which is above the threshold value of $8 \%$ for avoiding spoiling processes $[59,81]$. The high amount of poppy seeds implied the need to further clean the camelina seeds (test not performed) before being delivered either to the industries for oil extraction or to farmers for sowing. Additionally, the lower bulk density of the collected material caused by the presence of MOG, could increase the cost for transportation, which is a key parameter for the economic sustainability of a biomass supply chain [82-84].

\section{Conclusions}

The cultivation of camelina for vegetable oil production can contribute to reduce the dependence on fossil as valid source for both energy production and raw material supply for industries. Meanwhile, the agricultural fields can benefit from the rotation of cereal crops with camelina. In Spain camelina is cultivated as winter crop and harvested in summer with a combine harvester equipped with cereal header. Seed yield was $0.95 \mathrm{Mg} \mathrm{ha}^{-1}$ which represented the $18.60 \%$ of the total aboveground biomass. Straw and siliques were not collected but chopped and returned to the ground. Currently a 
proper supply chain for their exploitation is still missing; proposals to use them as fuel for bioenergy production are found in literature, but still not confirmed at the industrial scale. The combine harvester performed better on camelina seeds harvesting in comparison with wheat, or other herbaceous oil crops as sunflower or cardoon in terms of TFC, EFC and FE, although the latter two species require a dedicated header. Harvesting cost was assessed in $65.97 € \mathrm{ha}^{-1}$ (or $69.42 € \mathrm{Mg}^{-1}$ if considered per $\mathrm{Mg}$ of seeds harvested) which is close the cost for wheat harvesting. However, the revenue may change according to the productivity and the market price of the two products. Interestingly, the seed loss was lower than reported by a similar study (even though a plot combine was used) but still not as low as found in other oil crops. Our findings suggest that $5.80 \%$ of seed loss out of the TSL of $7.2 \%$ derives from the ineffectiveness of the cleaning shoe of the combine harvester, then supporting the hypothesis that further investigations as well as improvements should be done in order to lower that value. Moreover, the harvested seed showed a high presence of MOG which can jeopardize the proper maintenance of the seeds (high moisture content) if impurities are not promptly removed. The lower bulk density could affect negatively the cost of transportation. In conclusion our findings address the main controversial passages of the camelina oil value chain, which are mainly linked to the harvesting stage. Reducing such aspects would in turn contribute to lower costs and increase the overall profitability of the value chain, thus further studies are encouraged to lower MOG content and seed loss.

Author Contributions: Conceptualization, W.S., F.L., S.B., L.P.; methodology, W.S., F.L., S.B., J.P.R.; data curation, W.S., F.L., S.B., C.A., J.P.R.; writing-original draft preparation, W.S., F.L., S.B., C.A.; writing-review and editing, W.S., F.L., S.B., L.P., J.P.R.; supervision, L.P.; funding acquisition, L.P. All authors have read and agreed to the published version of the manuscript.

Funding: This research was funded by PRIMA foundation, project 4CE-MED, grant Number 1911, a program supported by the European Union.

Acknowledgments: The authors wish to thank Camelina Company (Camino de la Carrera, 11-11, 28140 Fuente el Saz, Madrid, Spain) for the organization of the tests and the support during the trials and Sandu Lazar for the help in performing the field and laboratory tests.

Conflicts of Interest: The authors declare no conflict of interest.

\section{References}

1. European Union (EU). Renewable Energy Directive II (EU) 2018/2001 11th December 2018. Available online: https://eur-lex.europa.eu/legal-content/IT/TXT/PDF/?uri=CELEX:32018L2001\&from=IT (accessed on 10 July 2020).

2. Maity, S.K. Opportunities, recent trends and challenges of integrated biorefinery: Part II. Renew. Sustain. Energy Rev. 2015, 43, 1446-1466. [CrossRef]

3. Silvestre, W.P.; Pauletti, G.F.; Baldasso, C. Fodder radish (Raphanus sativus L.) seed cake as a feedstock for pyrolysis. Ind. Crops Prod. 2020, 154, 112689. [CrossRef]

4. Suardi, A.; Latterini, F.; Alfano, V.; Palmieri, N.; Bergonzoli, S.; Karampinis, E.; Kougioumtzis, M.A.; Grammelis, P.; Pari, L. Machine Performance and Hog Fuel Quality Evaluation in Olive Tree Pruning Harvesting Conducted Using a Towed Shredder on Flat and Hilly Fields. Energies 2020, 13, 1713. [CrossRef]

5. Suardi, A.; Stefanoni, W.; Bergonzoli, S.; Latterini, F.; Jonsson, N.; Pari, L. Comparison between Two Strategies for the Collection of Wheat Residue after Mechanical Harvesting: Performance and Cost Analysis. Sustainability 2020, 12, 4936. [CrossRef]

6. Cocco, D.; Deligios, P.A.; Ledda, L.; Sulas, L.; Virdis, A.; Carboni, G. LCA study of oleaginous bioenergy chains in a Mediterranean environment. Energies 2014, 7, 6258-6281. [CrossRef]

7. Dangol, N.; Shrestha, D.S.; Duffield, J.A. Life-cycle energy, GHG and cost comparison of camelina-based biodiesel and biojet fuel. Biofuels 2017, 11, 1-9. [CrossRef]

8. Carlsson, A.S. Plant oils as feedstock alternatives to petroleum-A short survey of potential oil crop platforms. Biochimie 2009, 91, 665-670. [CrossRef]

9. Bessou, C.; Ferchaud, F.; Gabrielle, B.; Mary, B. Biofuels, greenhouse gases and climate change. A review. Agron. Sustain. Dev. 2011, 31, 1-79. [CrossRef] 
10. Pari, L.; Suardi, A.; Stefanoni, W.; Latterini, F.; Palmieri, N. Environmental and Economic Assessment of Castor Oil Supply Chain: A Case Study. Sustainability 2020, 12, 6339. [CrossRef]

11. Paulsen, H.M.; Wichmann, V.; Schuemann, U.; Richter, B. Use of straight vegetable oil mixtures of rape and camelina as on farm fuels in agriculture. Biomass Bioenergy 2011, 35, 4015-4024. [CrossRef]

12. Esteban, B.; Riba, J.-R.; Baquero, G.; Rius, A.; Puig, R. Temperature dependence of density and viscosity of vegetable oils. Biomass Bioenergy 2012, 42, 164-171. [CrossRef]

13. Haas, M.J.; McAloon, A.J.; Yee, W.C.; Foglia, T.A. A process model to estimate biodiesel production costs. Bioresour. Technol. 2006, 97, 671-678. [CrossRef] [PubMed]

14. Amigun, B.; Sigamoney, R.; von Blottnitz, H. Commercialisation of biofuel industry in Africa: A review. Renew. Sustain. Energy Rev. 2008, 12, 690-711. [CrossRef]

15. Keske, C.M.H.; Hoag, D.L.; Brandess, A.; Johnson, J.J. Is it economically feasible for farmers to grow their own fuel? A study of Camelina sativa produced in the western United States as an on-farm biofuel. Biomass Bioenergy 2013, 54, 89-99. [CrossRef]

16. Yang, J.; Caldwell, C.; Corscadden, K.; He, Q.S.; Li, J. An evaluation of biodiesel production from Camelina sativa grown in Nova Scotia. Ind. Crops Prod. 2016, 81, 162-168. [CrossRef]

17. Tepelus, A.; Rosca, P.; Dragomir, R. Biojet from hydroconversion of camelina oil mixed with straight run gas oil. Rev. Chim. 2019, 70, 3284-3291. [CrossRef]

18. Mohammad, B.T.; Al-Shannag, M.; Alnaief, M.; Singh, L.; Singsaas, E.; Alkasrawi, M. Production of multiple biofuels from Whole Camelina Material: A renewable energy crop. BioResources 2019, 13, 4870-4883.

19. Natelson, R.H.; Wang, W.C.; Roberts, W.L.; Zering, K.D. Technoeconomic analysis of jet fuel production from hydrolysis, decarboxylation, and reforming of camelina oil. Biomass Bioenergy 2015, 75, 23-34. [CrossRef]

20. Pietras, M.P.; Orczewska-Dudek, S. The effect of dietary camelina sativa oil on quality of broiler chicken meat. Ann. Anim. Sci. 2013, 13, 869-882. [CrossRef]

21. Orczewska-Dudek, S.; Pietras, M. The effect of dietary Camelina sativa oil or cake in the diets of broiler chickens on growth performance, fatty acid profile, and sensory quality of meat. Animals 2019, 9, 734. [CrossRef]

22. Halmemies-Beauchet-Filleau, A.; Shingfield, K.J.; Simpura, I.; Kokkonen, T.; Jaakkola, S.; Toivonen, V.; Vanhatalo, A. Effect of incremental amounts of camelina oil on milk fatty acid composition in lactating cows fed diets based on a mixture of grass and red clover silage and concentrates containing camelina expeller. J. Dairy Sci. 2017, 100, 305-324. [CrossRef] [PubMed]

23. Hixson, S.M.; Parrish, C.C.; Anderson, D.M. Use of camelina oil to replace fish oil in diets for farmed salmonids and atlantic cod. Aquaculture 2014, 431, 44-52. [CrossRef]

24. Toyes-Vargas, E.A.; Parrish, C.C.; Viana, M.T.; Carreón-Palau, L.; Magallón-Servín, P.; Magallón-Barajas, F.J. Replacement of fish oil with camelina (Camelina sativa) oil in diets for juvenile tilapia (var. GIFT Oreochromis niloticus) and its effect on growth, feed utilization and muscle lipid composition. Aquaculture 2020, 523, 735177. [CrossRef]

25. Pernak, J.; Łegosz, B.; Klejdysz, T.; Marcinkowska, K.; Rogowski, J.; Kurasiak-Popowska, D.; StuperSzablewska, K. Ammonium bio-ionic liquids based on camelina oil as potential novel agrochemicals. RSC Adv. 2018, 8, 28676-28683. [CrossRef]

26. Pawlowska-Olszewska, M.; Puzio, I.; Harrison, A.P.; Borkowski, L.; Tymicki, G.; Grabos, D. Supplementation with camelina oil prevents negative changes in the artery in orchidectomized rats. J. Physiol. Pharmacol. 2018, 69, 109-116. [PubMed]

27. Omonov, T.S.; Kharraz, E.; Curtis, J.M. Camelina (Camelina Sativa) oil polyols as an alternative to Castor oil. Ind. Crops Prod. 2017, 107, 378-385. [CrossRef]

28. Cherian, G.; Campbell, A.; Parker, T. Egg quality and lipid composition of eggs from hens fed Camelina sativa. J. Appl. Poult. Res. 2009, 18, 143-150. [CrossRef]

29. Giuliano, A.; Cerulli, R.; Poletto, M.; Raiconi, G.; Barletta, D. Optimization of a Multiproduct Lignocellulosic Biorefinery using a MILP Approximation. In 24 European Symposium on Computer Aided Process Engineering; Klemeš, J.J., Varbanov, P.S., Liew, P.Y., Eds.; Elsevier: Amsterdam, The Netherlands, 2014; Volume 33, pp. 1423-1428. ISBN 1570-7946.

30. Murphy, E.J. Camelina (Camelina sativa). In Industrial Oil Crops; McKeon, T.A., Hayes, D.G., Hildebrand, D.F., Weselake, R.J., Eds.; Elsevier: Amsterdam, The Netherlands, 2016; pp. 207-230. ISBN 978-1-893997-98-1. 
31. Gesch, R.W.; Archer, D.W. Double-cropping with winter camelina in the northern Corn Belt to produce fuel and food. Ind. Crops Prod. 2013, 44, 718-725. [CrossRef]

32. Zanetti, F.; Gesch, R.W.; Walia, M.K.; Johnson, J.M.F.; Monti, A. Winter camelina root characteristics and yield performance under contrasting environmental conditions. Field Crops Res. 2020, 252, 107794. [CrossRef]

33. Gesch, R.W.; Archer, D.W.; Berti, M.T. Dual cropping winter camelina with soybean in the northern corn belt. Agron. J. 2014, 106, 1735-1745. [CrossRef]

34. Chen, C.; Bekkerman, A.; Afshar, R.K.; Neill, K. Intensification of dryland cropping systems for bio-feedstock production: Evaluation of agronomic and economic benefits of Camelina sativa. Ind. Crops Prod. 2015, 71, 114-121. [CrossRef]

35. Berti, M.; Samarappuli, D.; Johnson, B.L.; Gesch, R.W. Integrating winter camelina into maize and soybean cropping systems. Ind. Crops Prod. 2017, 107, 595-601. [CrossRef]

36. Royo-Esnal, A.; Valencia-Gredilla, F. Camelina as a Rotation Crop for Weed Control in Organic Farming in a Semiarid Mediterranean Climate. Agriculture 2018, 8, 156. [CrossRef]

37. Peterson, A.T.; Berti, M.T.; Samarappuli, D. Intersowing cover crops into standing soybean in the US upper midwest. Agronomy 2019, 9, 264. [CrossRef]

38. Zanetti, F.; Christou, M.; Alexopoulou, E.; Berti, M.T.; Vecchi, A.; Borghesi, A.; Monti, A. Innovative double cropping systems including camelina [camelina sativa (L.) crantz] a valuable oilseed crop for bio-based applications. In Proceedings of the European Biomass Conference and Exhibition Proceedings, Lisbon, Portugal, 27-30 May 2019; pp. 127-130.

39. Li, X.; Mupondwa, E. Life cycle assessment of camelina oil derived biodiesel and jet fuel in the Canadian Prairies. Sci. Total Environ. 2014, 481, 17-26. [CrossRef]

40. Lohaus, R.H.; Neupane, D.; Mengistu, M.A.; Solomon, J.K.Q.; Cushman, J.C. Five-Year Field Trial of Eight Camelina sativa Cultivars for Biomass to be Used in Biofuel under Irrigated Conditions in a Semi-Arid Climate. Agronomy 2020, 10, 562. [CrossRef]

41. Christopher, L.P.; Kumar, H.; Zambare, V.P. Enzymatic biodiesel: Challenges and opportunities. Appl. Energy 2014, 119, 497-520. [CrossRef]

42. FAO. FAO Global agriculture towards 2050. In How to Feed World; FAO: Rome, Italy, 2009.

43. Gui, M.M.; Lee, K.T.; Bhatia, S. Feasibility of edible oil vs. non-edible oil vs. waste edible oil as biodiesel feedstock. Energy 2008, 33, 1646-1653. [CrossRef]

44. Bušić, A.; Kundas, S.; Morzak, G.; Belskaya, H.; Mardetko, N.; Šantek, M.I.; Komes, D.; Novak, S.; Šantek, B. Recent trends in biodiesel and biogas production. Food Technol. Biotechnol. 2018, 56, 152-173. [CrossRef]

45. Latterini, F.; Stefanoni, W.; Suardi, A.; Alfano, V.; Bergonzoli, S.; Palmieri, N.; Pari, L. A GIS Approach to Locate a Small Size Biomass Plant Powered by Olive Pruning and to Estimate Supply Chain Costs. Energies 2020, 13, 3385. [CrossRef]

46. Pari, L.; Latterini, F.; Stefanoni, W. Herbaceous Oil Crops, a Review on Mechanical Harvesting State of the Art. Agriculture 2020, 10, 309. [CrossRef]

47. Zubr, J. Qualitative variation of Camelina sativa seed from different locations. Ind. Crops Prod. 2003, 17, 161-169. [CrossRef]

48. Vollmann, J.; Moritz, T.; Kargl, C.; Baumgartner, S.; Wagentristl, H. Agronomic evaluation of camelina genotypes selected for seed quality characteristics. Ind. Crops Prod. 2007, 26, 270-277. [CrossRef]

49. Obour, K.A. Oilseed Camelina (Camelina sativa L Crantz): Production Systems, Prospects and Challenges in the USA Great Plains. Adv. Plants Agric. Res. 2015, 2, 1-10. [CrossRef]

50. Leclère, M.; Jeuffroy, M.-H.; Butier, A.; Chatain, C.; Loyce, C. Controlling weeds in camelina with innovative herbicide-free crop management routes across various environments. Ind. Crops Prod. 2019, 140, 111605. [CrossRef]

51. Sintim, H.Y.; Zheljazkov, V.D.; Obour, A.K.; Garcia y Garcia, A. Managing harvest time to control pod shattering in oilseed camelina. Agron. J. 2016, 108, 656-661. [CrossRef]

52. Stolarski, M.J.; Krzyżaniak, M.; Tworkowski, J.; Załuski, D.; Kwiatkowski, J.; Szczukowski, S. Camelina and crambe production-Energy efficiency indices depending on nitrogen fertilizer application. Ind. Crops Prod. 2019, 137, 386-395. [CrossRef]

53. NSAI ISO 18134-2:2017 Solid Biofuels—Determination of Moisture Content—Oven Dry Method—Part 2: Total Moisture-Simplified Method. Available online: https://www.iso.org/standard/71536.html (accessed on 6 July 2020). 
54. ISO 17828:2015 ISO 17828:2015 Solid Biofuels—Determination of Bulk Density. Available online: https: //www.iso.org/obp/ui/\#iso:std:iso:17828:ed-1:v1:en (accessed on 23 July 2020).

55. Assirelli, A.; Croce, S.; Acampora, A.; Civitarese, V.; Suardi, A.; Santangelo, E.; Pari, L. An Innovative System for Conditioning Biomass [Sorghum bicolo (L.) Moench.]. Am. Soc. Agric. Biol. Eng. 2013, 56, 829-837.

56. Assirelli, A.; Pignedoli, S. Costo di esercizio delle macchine agricole. Cent. Ric. e Prod. Anim. 2005, 5, 1-10.

57. Banca d'Italia Banca d'Italia Lending Rate. Available online: https://www.bancaditalia.it/ (accessed on 11 July 2020).

58. Statsoft Website. Available online: https://www.statsoft.de/en/home (accessed on 5 July 2020).

59. Mauri, P.V.; Mostaza, D.; Plaza, A.; Ruiz-Fernandez, J.; Prieto, J.; Capuano, A. Variability of camelina production in the center of Spain in two years of cultivation, a new profitable and alternative crop. In Proceedings of the 27th European Biomass Conference and Exhibition, Lisbon, Portugal, 27-30 May 2019; pp. 196-200.

60. Schillinger, W.F. Camelina: Long-term cropping systems research in a dry Mediterranean climate. Field Crops Res. 2019, 235, 87-94. [CrossRef]

61. Imbrea, F.; Jurcoane, S.; Hǎlmǎjan, H.V.; Duda, M.; Botoş, L. Camelina sativa: A new source of vegetal oils. Rom. Biotechnol. Lett. 2011, 16, 6263-6270.

62. FAO FAOSTAT Agriculture Data. Available online: http://www.fao.org/faostat/en/\#data (accessed on 30 August 2020).

63. Hernando, H.; Fermoso, J.; Moreno, I.; Coronado, J.M.; Serrano, D.P.; Pizarro, P. Thermochemical valorization of camelina straw waste via fast pyrolysis. Biomass Convers. Biorefinery 2017, 7, 277-287. [CrossRef]

64. Olughu, O.O.; Tabil, L.G.; Dumonceaux, T. Effect of Ultrasonic Pretreatment on the Chemical Composition and Pellet Quality of Camelina Straw. In Proceedings of the 2019 ASABE Annual International Meeting, Boston, MA, USA, 7-10 July 2019; American Society of Agricultural and Biological Engineers: St. Joseph, MI, USA; p. 1.

65. Krzyżaniak, M.; Stolarski, M.J.; Graban, Ł.; Lajszner, W.; Kuriata, T. Camelina and Crambe Oil Crops for Bioeconomy-Straw Utilisation for Energy. Energies 2020, 13, 1503. [CrossRef]

66. Suardi, A.; Stefanoni, W.; Alfano, V.; Bergonzoli, S.; Pari, L. Equipping a Combine Harvester with Turbine Technology Increases the Recovery of Residual Biomass from Cereal Crops via the Collection of Chaff. Energies 2020, 13, 1572. [CrossRef]

67. Suardi, A.; Saia, S.; Stefanoni, W.; Gunnarsson, C.; Sundberg, M.; Pari, L. Admixing Chaff with Straw Increased the Residues Collected without Compromising Machinery Efficiencies. Energies 2020, 13, 1766. [CrossRef]

68. Chaplygin, M.; Bespalova, O.; Podzorova, M. Results of tests of devices for sunflower harvesting in economic conditions. E3S Web Conf. 2019, 126, 1-7. [CrossRef]

69. Pari, L.; Fedrizzi, M.; Gallucci, F. Cynara cardunculus exploitation for energy applications: Development of a combine head for thesing and concurrent residues collecting and utilization. In Proceedings of the 16th European Biomass Conference \& Exhibition, Valencia, Spain, 2-6 June 2008.

70. Pari, L.; Alfano, V.; Acampora, A.; Del Giudice, A.; Scarfone, A.; Sanzone, E. Harvesting and Separation of Different Plant Fractions in Cynara cardunculus L. In Perennial Biomass Crops for a Resource-Constrained World; Barth, S., Murphy-Bokern, D., Kalinina, O., Taylor, G., Jones, M., Eds.; Springer: Berlin/Heidelberg, Germany, 2016; pp. 261-271. ISBN 978-3-319-44529-8.

71. Semerci, A.; Kaya, Y. The Components of Production Cost in Sunflower and its Relationships with Input Prices. Int. Rev. Appl. Econ. 2010, 5, 139-146.

72. Semerci, A. Cost analysis of oily sunflower production: The case of Tekirdag province, Turkey. Custos $e$ Agronegocio 2019, 15, 167-191.

73. Bergonzoli, S.; Suardi, A.; Rezaie, N.; Alfano, V.; Pari, L. An innovative system for Maize Cob and wheat chaff harvesting: Simultaneous grain and residues collection. Energies 2020, 13, 1265. [CrossRef]

74. Wiwart, M.; Kurasiak-Popowska, D.; Suchowilska, E.; Wachowska, U.; Stuper-Szablewska, K. Variation in the morphometric parameters of seeds of spring and winter genotypes of Camelina sativa (L.) Crantz. Ind. Crops Prod. 2019, 139, 111571. [CrossRef]

75. Startsev, A.S.; Demin, E.E.; Danilin, A.V.; Vasilyev, O.A.; Terentyev, A.G. Results of the production test of sunflower harvesting attachment with an auger reel. IOP Conf. Ser. Earth Environ. Sci. 2020, 433, 012006. [CrossRef] 
76. Shaforostov, V.D.; Makarov, S.S. The header for a breeding plot combine for sunflower harvesting. Acta Technol. Agric. 2019, 22, 60-63. [CrossRef]

77. Asoodar, A.M.; Izadinia, Y.; Desbiolles, J. Benefits of harvester front extension in reducing canola harvest losses. Int. Agric. Eng. J. 2012, 21, 32-37.

78. Pari, L.; Assirelli, A.; Suardi, A. Evaluation of Brassica napus and Brassica carinata losses during harvesting: Three years of experience. In Proceedings of the 18th European Biomass Conference and Exhibition Proceedings, Lyon, France, 3-7 May 2010; pp. 1790-1793.

79. Pari, L.; Assirelli, A.; Suardi, A.; Civitarese, V.; Del Giudice, A.; Costa, C.; Santangelo, E. The harvest of oilseed rape (Brassica napus L.): The effective yield losses at on-farm scale in the Italian area. Biomass Bioenergy 2012, 46, 453-458. [CrossRef]

80. Reginato, P. Colheita Mecanizada de Sementes de Crambe (Crambe abyssinica L.) no Cerrado Sul Mato Grossense. Ph.D. Thesis, Universidade Federal da Grande Dourados, Dourados, Brazil, 2014.

81. Grady, K.; Nleya, T. Camelina Production. Ext. Extra, South Dakota State Univ. 2010, 8167, 1-3.

82. Ma, S.; Eckhoff, S.R. Economy of scale for biomass refineries: Bulk densities, transportation cost, and producer incentives. Trans. ASABE 2014, 57, 85-91.

83. Eisenbies, M.H.; Volk, T.A.; Therasme, O.; Hallen, K. Three bulk density measurement methods provide different results for commercial scale harvests of willow biomass chips. Biomass Bioenergy 2019, 124, 64-73. [CrossRef]

84. Picchio, R.; Latterini, F.; Venanzi, R.; Stefanoni, W.; Suardi, A.; Tocci, D.; Pari, L. Pellet Production from Woody and Non-Woody Feedstocks: A Review on Biomass Quality Evaluation. Energies 2020, $13,2937$. [CrossRef]

(C) 2020 by the authors. Licensee MDPI, Basel, Switzerland. This article is an open access article distributed under the terms and conditions of the Creative Commons Attribution (CC BY) license (http://creativecommons.org/licenses/by/4.0/). 